Special issue.2005.V 1.N 4.P. 6-22.

\title{
INTELLECTUAL PROPERTY LAW AND BIOTECHNOLOGICAL INVENTIONS FOR THE COUNTRIES IN TRANSITION TO MARKET ECONOMY
}

\author{
Mr.Jeno Bobrovszky \\ Former Director of the Division for Cooperation with Certain Countries in Europe and Asia, \\ World Intellectual Property Organization (WIPO)
}

\begin{abstract}
Mr. Jeno Bobrovszky is the former Director, Division for Cooperation with Certain Countries in Europe and Asia, World Intellectual Property Organization (WIPO). He retired in 2005, after 14 years of service as UN diplomat. Mr. Bobrovszky graduated with a Doctor of Law and Politology degree from the University of Budapest in 1965. He also holds a postgraduate Patent Expert degree from the Moscow Patent Academy (1976), a Ph.D. (1976) and a D.Sc. (Doctor of Juridical Sciences, 1992) from the Hungarian Academy of Sciences for his thesis on intellectual property topics. Before joining WIPO in 1991 as Head of Industrial Property Law Section and later of Enforcement Section he was Director of the Legal, Trademark and International Department of the Hungarian Patent Office from 1977 to 1991. From 1973 to 1977 , he worked as an intellectual property expert in the Secretariat of the Council for Mutual Economic Assistance (CMEA), Moscow. He has been a member of the International Association for the Advancement of Teaching and Research in Intellectual Property (ATRIP) since 199. He was in charge at WIPO of the massive modernization of intellectual property legislation, institutional systems and human resources in 30 countries in transition to market economy.
\end{abstract}

\begin{abstract}
Governments are competing for attracting foreign direct investment (FDI) as a form of international economic transaction which is perceived as an important source of technological, economic and social developments of the countries and as an instrument of international economic integration. The investment climate is determined by a broader environment, a set of factors, e.g. a large market size, as measured by population, per capita income (purchasing power), GDP growth rate, low trade barriers, level of privatization, candidate or membership status in the World Trade Organization (WTO), increases the confidence and attractiveness of a host country, sends positive signals to investors. On the other hand, slow market entry procedures, corruption, underdeveloped infrastructure and regional tensions all act as deterrents to foreign investments. One of the most important factors of the national policy framework determining investment environment is the strength of intellectual property protection. Empirical analysis results show that weak protection of intellectual property rights discourages foreign investors. The deterring effect of inadequate IPR regime is particularly strong in four technology-intensive sectors: drugs, cosmetics and healthcare products; chemicals; machinery and electrical equipment.
\end{abstract}




\section{Technologies, innovation management and technology transfer}

\section{BACKGROUND: INTELLECTUAL PROPERTY IN GENERAL}

\section{The subject matter of intellectual property}

For the purposes of this book the subject matters of intellectual property are creations of mind and other intellectual values.

\section{Creations of mind are:}

- ideas as functional (technical, useful, utilitarian) creations (inventions, utility models, layout designs of integrated circuits, new plant varieties, trade secrets, knowhow);

- forms of expressions (industrial designs, literary, artistic or scientific works as expressive creations).

Other intellectual values those are commercially valuable as:

- goodwill (represented by trademarks, trade names, geographical indications) and personal reputation (character merchandizing);

- certain products of intellectual efforts (performances of artists, producers of phonograms, broadcasting organizations, not original database).

The above listed creations of the mind and other intellectual values of intangible nature enjoy different levels of property-like exclusive rights to help exploit them on the market. This is made possible by the fact that the creations of the mind and other intellectual values have a common denominator, namely, that they may become intellectual quality components of market commodities. For example, in a wristwatch ("utilitarian products" or industrial goods") the functional intellectual quality-the technological content-is based on an invention, the watch's visual appearance, the ornamental intellectual quality on an industrial design and its commercial symbol as a trademark, as a distinctive sign determines its marketing intellectual quality. A medium of expression (e. g. a compact disk) combines the functional content with a literary or artistic expression ("cultural products" or "copyright goods").

The majority of the creations of the mind, such as inventions, utility models, layout designs of integrated circuits, plant varieties, trade secrets, know-how as the practical application of ideas (knowledge, information), play an important role in the innovation of the functional quality of goods determined by their technological (utilitarian) features. Other intellectual creations, such as industrial designs and works of applied art, serve as a basis for upgrading the formal quality determined by the visual, aesthetic appearance, the "look" of the goods.

Commercial symbols such as trademarks, trade names and geographical indications are used to develop the marketing quality of goods and services by distinguishing them or the companies or geographic regions from which they originate or take their reputation, goodwill or trade value.

\section{The rationale of the protection of intellectual property}

Creations of the mind and commercial symbols as intangible assets may have two kinds of market commodity embodiments for commercial purposes:

- useful, functional creations of the mind can be incorporated in useful articles (watches, cameras, medicines, etc.);

- the forms of expressions as creations of the mind, whether useful or literary or artistic, can be incorporated in a tangible medium of expression (a description, a drawing, a film, a compact disk, etc.). 


\section{Special Issue}

Industrial designs can be reproduced in and commercial symbols can be affixed both to useful, functional articles and media of expression.

As a consequence of the intangible nature of intellectual values, there are no natural restraints or time and space limits on the exploitation of their embodiment, simultaneously or successively by several parties anywhere in the world.

While, on the one hand, the pioneering of new technology and the creation and exploitation of other intellectual values as intangible assets require increasingly important investment costs, time, efforts and significant risktaking at the research, development and production stage, it is, on the other hand, technically easy and cheap to imitate those assets. If imitation is not prevented, a creator or innovator of such intellectual values cannot recover his risk capital investments with appropriate profits in the market place and will lose his economic motivation and resources for further innovation where the failure is more common than the success. The aim of the protection is to create a market mechanism by legally preventing the possibility of "free ride" that is the illicit use of those intangible assets by third parties for commercial purposes. By allowing the recovery of investments with appropriate profit on the market the protection promotes:

- the progress of creativity and innovations in technology, economy, culture; the diversification and upgrading of the quality of the products based on the creations;

- the material and moral reward of the creators and performers through the commercialization;

- the disclosure of the creations of the mind in order to make them gradually available to the public;

- maintaining fair competition;

- the transfer of technology, mainly through licensing;

- the attraction of foreign direct investments in innovations.
The aim of the protection afforded to commercial symbols is the development of the market by permitting branded goods or services to be distinguished as to their origin, their quality and through their advertising among the consumers. Commercial symbols represent the goodwill of goods and services in connection with which a mark is used. The goodwill represents the value of an enterprise that reflects its commercial reputation and can be translated in the market into a higher profit.

As to the philosophy of the protection of intellectual property, one can differentiate among three theories as follows:

- assertive, positive, proprietarianist theories, justifying the existence and the maximization ("overprotection") of intellectual property (referring to natural laws, human and personality rights, moral principles of property and reward of creativity, the necessity of return on innovative investments, etc.);

- nihilist, negative, antiproprietarianist theories, denying the intellectual property or trying to minimize ("underprotect") it (referring to the natural right of society to imitate, the importance of public domain or intellectual commons, the advantages of direct incentives over market mechanism, etc.);

- synthetic, "quid pro quo", instrumentalist theories, justifying the private intellectual property as a social contract with certain counterbalances for the benefit of the public (referring to the utilitarianism, the necessity of proper balance, a trade-off between the private and public interests, the incentives for creativity and innovative investments on the one hand and the rights of competitors, non-commercial users and the general public for the accession and use of creations i.e. an equilibrium between intellectual property exclusivity and regulated freedom for users).

SCIENCE AND INNOVATION. N 4, 2005 


\section{Technologies, innovation management and technology transfer}

\section{The main principles of intellectual property}

The protection of intellectual property is based on a number of principles aimed at securing desirable balance between private and public interests, exclusive rights and free competition.

The leading principle in a market economy is the freedom of competition from which it follows that the freely usable public domain is the rule and intellectual property is the exception. Intellectual property as a private right is available only under certain conditions, for new, original, non-obvious or distinctive intellectual creations, which exceed the public domain and the intellectual property of others.

A practical consequence of this situation is that the competitive right of free use of public domain information and of unprotected technical (functional, utilitarian) features in the area of publicly available generic products that are not eligible for protection or for which protection has lapsed is usually acknowledged and encouraged, provided that there is no likelihood of confusion as to the source of the products and that the appropriation cannot be qualified as a mere "free ride" copying or slavish imitation of an achievement having distinctive features.

In this respect, reverse engineering (decomposition or dismantling) is commonly practiced in the industry in connection with the publicly available, unprotected products of competitors, for the purpose of learning the technology embodied in the products and eventually producing competing products without actually copying anything from the original or violating the rules against unfair competition.

Intellectual property and competition laws are complementary because they both aim at promoting competitive pressure as driving force to promote creativity and innovation. However, the legal exclusivity granted by intellectual property rights may lead to anti-competitive market power, predatory pricing, abuses of dominant position or even monopoly as defined under competition law. There is a difference between the existence and possible anti-competitive exercise of those rights.

According to the antitrust laws, intellectual property in itself is regarded as being comparable to any other form of property so it cannot be presumed that intellectual property creates market power in the antitrust context. Licensing is also generally pro-competitive, allowing forms to combine complementary factors of production. However, certain licensing arrangement may adversely effect competition (restraints, tying arrangement, exclusive dealings, etc.).

Another important principle is the limitation of the protection of creations of the mind and commercial symbols.

For example, intellectual property does not protect an idea as such, in an absolute sense, but only the specific expression of an idea (by copyright) or the practical application (functionality) of an idea (knowledge, information) in a useful article.

On the other hand, it is a legitimate and encouraged competitive behavior to further develop a patented invention for a derivative new product or process that does not infringe the patent but produces the same or a better result than the patented invention ("inventing or designing around"). The public as a rule has right for the non-commercial, "fair-use" of protected intellectual values.

Intellectual property does not confer positive ownership rights in the creations of the mind; it is a preventive exclusion right regarding certain market activities of others for the commercialization of creations of the mind ("to make, to use, to sell") without the consent of the right holder, within constraints of time, territory, fair use exemptions (e.g., free use for teaching purposes) and public interest (e.g., anti-trust rules, consumer protection). Furthermore, intellectual property does not constitute market 


\section{Special Issue}

authorization, confer a right of exploitation of the creations of the mind; that right is governed by other, market regulatory rules (e.g. in case of pharmaceutical products).

Intellectual property protection is by nature territorial and temporary and is aimed at channeling intellectual creations into the public domain once the exclusive right has lapsed. That is the general, final and irreversible status of non proprietary intellectual creations and commercial symbols that are not or not anymore protected by a specific form of intellectual property. Public domain items cannot be appropriated for private purposes and are available for free copying and use by anyone as a part of the public's cultural heritage (intellectual commons).

The general ideas on the one hand and the obvious, commonplace, routine solutions, generic elements, signs on the other hand are also part of public domain.

It has to be mentioned that there are many works that are not part of the public domain but for which the owner of some proprietary rights has chosen not to enforce those rights (e.g. Free Software Foundation which licenses copyrighted software without royalty under the license "copyleft").

A copyright holder as a rule can explicitly disclaim any proprietary interest in the work, effectively granting it to the public domain.

With regards to patents on the other hand, publishing the details of an invention before applying for a patent will generally place an invention in the public domain.

One of the purposes of the patent system is to put new technologies into the public domain, through its informative functions. For example, the grant of a patent is conditional on the disclosure of the invention as a quid pro quo, that is, the giving up of the secrecy of the invention. The publication of the invention by a Patent Office makes it accessible to the public and enables others to understand the invention, to be inspired by it and to use it for research or experiments (depending on the applicable patent law) as a stepping stone to further developments of the technology. Also, once a patent has expired, the public is allowed and encouraged to use the invention belonging to the public domain.

Patents of inventions provide a shorter term of protection but a right of preventing exploitation of ideas; copyright gives a longer term of protection for the forms of expressions but it only allows to prevent copying while the term of protection of commercial symbols representing the identity of a product under the changing market conditions, can be extended without limitation.

\section{Intellectual property legal options}

Intellectual property consists of various elements which can be alternatively chosen or cumulatively combined to secure as a portfolio of rights an efficient protection, depending on the form of exploitation (communicative or productive) of the multidimensional, polyvalent, hybrid intellectual values. The principal specific forms of protection are provided:

- by industrial property rights (patents for inventions, utility models, trade secrets, industrial design, trademark rights, etc.) concerning the incorporation of a functional creation of the mind in a useful article or the reproduction of a design in or the affixation of a commercial symbol to a useful article or to a medium of expression;

- by copyright concerning the embodiment of the literary or artistic forms of expression in a tangible medium of expression or as intangible assets without fixation.

Supplementary forms of protection-as a general kind and second line of defense in the absence of specific protection-are provided for by the laws against unfair competition, in par- 


\section{Technologies, innovation management and technology transfer}

ticular the provisions regarding trade secret protection of undisclosed information, protection against taking undue advantage (e.g., by slavish imitation or other forms of free riding) or causing confusion (e.g., by passing off) in the market in the course of competition.

Finally, certain non-specific complementary forms of protection can be based on the general principles and institutions of the legal systems, in particular on the commercial or civil laws (law of contracts and torts), labor law (regarding employee creations, trade secret protection, etc.) and administrative and criminal law (concerning counterfeiting and piracy, etc.).

Generally speaking, each country, on the basis of its legislative sovereignty and the territorial principle, has its own intellectual property laws and its national system of organizations functioning in the field of intellectual property protection.

The national intellectual property laws and practices differ from country to country, although some global minimum standards have been accepted and a certain degree of harmonization has been reached through normative international treaties, in particular the Paris Convention for the Protection of Industrial Property, the Berne Convention for the Protection of Literary and Artistic Works, the Agreement on the Trade-Related Aspects of Intellectual Property Rights (TRIPS Agreement), the Trademark Law Treaty and the Patent Law Treaty (PLT). For the details see Annex 1.

The general provisions and basic principles of the TRIPS Agreement are those of national treatment and most-favored-nation treatment. Thus, members of the WTO must accord the nationals of other member treatment no less favorable than they accord to their own nationals. Moreover, any advantage granted by a member to nationals of another member must be accorded immediately and unconditionally to the nationals of all other members even if this treatment is more favorable than that accorded to its own nationals.

The TRIPS Agreement aims to ensure that adequate rules and effective level of the protection of intellectual property are applied in all member countries, on the basis of the basic obligations laid down by WIPO in the various conventions on intellectual property rights, particularly the Paris Convention for the Protection of Industrial Property. Numerous new rules or stricter rules are introduced in fields not covered by the existing conventions or where the existing conventions are inadequate to reduce distortion and impediments to international trade from different standards of protection.

The TRIPS Agreement covers a vast range of topics, from copyright and trademarks to layout-designs of integrated circuits and trade secrets. It deals with each of the main categories of intellectual property, establishes standards of protection and rules on enforcement, and provides for the application of the WTO dispute settlement mechanism to resolve disputes between member states. One feature of the TRIPS Agreement is that the protection of intellectual property has become an integral part of the multilateral trading system as reflected by the WTO. The failure of a country to meet its TRIPS obligations can jeopardize its market access rights and other benefits under the WTO.

The harmonization of norms is in constant progress. Furthermore, in addition to the normative treaties, certain operative (filing, registration and granting) systems for patents, trademarks, industrial designs and appellations of origin facilitate the acquisition rights, in particular through the Patent Cooperation Treaty (PCT), the Madrid Agreement Concerning the International Registration of Marks, the Hague Agreement Concerning the International Deposit of Designs and the Lisbon Agreement for the Protection of Appellations of Origin and their International Registration. 


\section{Special Issue}

As to the regional cooperation in the world, one can differentiate between:

- only common rules, normative type cooperation (in South America: Andean Community countries, Central American Convention, Common Market of the South, Group of three, North American Free Trade Agreement, ASEAN Framework Agreement);

- common rules, normative type and common office, operative type "double cooperation" exists in Europe, C.I.S, and Africa. There are two types of common office, operative cooperation: centralized procedure of granting national rights (European Patent Office "EPO"), African Regional Industrial Property Organization "ARIPO") or centralized procedure of granting unitary (supranational) regional rights (Community Trademark "OHIM", Eurasian Patent Convention "EAPO", African Intellectual Property Organization "OAPI", Gulf Cooperation Council Patent Office).

\section{EU Directive on enforcement of intellectual property rights}

The Directive seeks to create a level playing field for the enforcement of intellectual property rights in different $\mathrm{EU}$ countries, by bringing enforcement measures into line across the EU, especially in those countries where the enforcement of intellectual property rights is currently weakest.

The Directive also aims to establish a general framework for the exchange of information between the responsible national authorities.

The Directive maintains a balance between helping holders of intellectual property defend their rights and protecting users from unfair litigation (so-called rights of due process).

The Directive covers infringements of all intellectual property rights (both copyright and industrial property, such as trademarks or designs) which under European law have been harmonized within the EU.

It concentrates on infringements carried out for commercial purposes or which cause significant harm to rightholders.

The Directive is based on best practice in the Member States. The measures it would extend throughout the EU include, among others, injunctions to halt the sale of counterfeit or pirate goods, provisional measures such as precautionary seizures of suspected offenders' bank accounts, evidence-gathering powers for judicial authorities and powers to force offenders to pay damages to rightholders to compensate for lost income.

Intellectual property rights need to be protected and enforced within carefully defined limits, for reasons which vary according to the different types of intellectual property.

These reasons are, for the main rights concerned:

- for patents, the point is to protect the inventive idea. This allows the inventor to generate income from their invention which thus gives a powerful incentive for inventors to create new inventions. In addition, patents are published and so information about new technical developments can be disseminated to other people who can make use of them;

- for trademarks, the point is to protect the link between producer and product e.g. the logo, packaging. This has two advantages, it allows consumers to identify the origin of the products they buy and hence choose the level of quality and safety they are prepared to pay for. Secondly, it gives a powerful incentive for rightholders to invest in their specific products and improve their quality and image;

- for copyright, the point is to protect the expression of a creative work such as a book, a piece of music, or a film. This allows the creator of the work and other righthold-

SCIENCE AND INNOVATION. N 4, 2005 


\section{Technologies, innovation management and technology transfer}

ers, to market creative content. IP serves to make available such content on appropriate terms. It also stimulates future creation and ensures the availability of high quality content for others to enjoy. Put simply, if an artist could not participate actively in the marketing of his or her work and get a share of the financial benefits, they would in most cases not be able to create and invest in their creation. If an intermediary like a film or record company did not get paid, they would not be able to produce and distribute it. Many major works enjoyed by millions would never see the light of day.

The term "fair use" comes from American practice. However, all EU Member States have certain exceptions to the rights in place, including for private copying or library use, which would roughly correspond to the idea of fair use. The Directive does not affect the scope of intellectual property law as established by existing EU and national law but only the enforcement of that law. E.g. there is a framework of EU law in place which does not make private lending subject to copyright protection.

Most Member States have exceptions in place in their national law regarding the copying of material in schools and libraries. In most cases therefore such use would be exempted from intellectual property rights and would not lead to an infringement in the first place.

The Directive does not introduce tougher sanctions against individuals downloading the odd track using file swapping software via their PCs for non-commercial purposes, thought it does not stop Member State authorities from introducing and applying tougher laws.

The scope of this proposal covers infringement carried out for commercial purposes or which cause significant harm to the rightholder.

File swapping may be considered a copyright infringement depending on the national law in question.

SCIENCE AND INNOVATION. N 4, 2005
The rule only covers illegal acts where authorization has not been given by the rightholder or where the appropriate remuneration has not been paid for the use of that piece of intellectual property.

Exchanging illegal content over the Internet is an illegal act or an infringement of copyright if it relates to music files.

Although considerable injury to rightholders can be caused by an individual via his/her computer linked to the Internet, it is not the interest of rightholders to spend a lot of time and money in litigation to catch offenders who are simply sharing a few files with a handful of friends.

The Directive aims to strike a fair balance between the interests of rightholders and legitimate users of intellectual property on the one hand and the wider opportunities the internet offers to consumers on the other, by focusing on commercial infringements or those which most damage rightholders' interests. It is not aimed at allowing the prosecution of large numbers of individuals using peer to peer (P2P) networks for casual file swapping.

For criminal sanctions to apply, the infringement must be "serious". An infringement is considered "serious" if carried out intentionally and for commercial purposes.

Although the Directive also includes references to proportionality, i.e. for the punishment to fit the crime, it is up to national judges to decide on sentencing on a case by case basis.

All EU Member States are bound by the rules of the TRIPS Agreement.

It is explicitly stated in the Directive that:

- none of its provisions in any way detracts from Member States' obligations under TRIPS;

- it does not set a limit on how far each Member State can go if it wants to go further than either TRIPS or indeed the provisions of the Directive itself. 


\section{Special Issue}

The Directive goes further than TRIPS, particularly for those infringements which pose the greatest threats to rightholders, namely infringements of IPRs which are either committed for commercial reasons or which cause "significant harm" to the rightholder.

These "TRIPS plus" elements are:

- a right of representation for collecting societies and trade associations;

- a power for the authorities to seize documentary evidence relating to the suspected infringement (as well as the suspect goods themselves);

- an obligation for courts to provide information on the source of infringing goods ("right of information");

- "interlocutory injunctions" (in advance of a decision on the merits of a case) to prevent suspected offenders and also intermediaries from profiting from an infringement;

- the seizure of offender's bank accounts and other assets and profits to ensure payment of due damages;

- the recall of infringing goods at the offender's own expense;

- the choice for the rightholder of either lump sum damages (up to double normal royalties or license fees) or compensation for lost profits;

- payment of legal costs (and "other expenses") by the offender where an infringement is established;

- the publication of court decisions;

- the winding up of companies found guilty of the most serious infringements;

- the banning of machines used to produce counterfeit security features for goods covered by industrial property rights (e.g. trademarks).

The Directive would make a difference in all Member States. Apart from its specific provisions, the Directive is also a political signal which will encourage national courts to apply sanctions and remedies more vigorously.

The more national laws within the EU are brought into line with one another, the more "common ground" that is developed. These similarities will make it easier for cross-border litigation in the future.

The Directive is based on existing best practice and that is not the preserve of one single Member State. In addition, provisions in national law are often complex and fall within many different legislative acts, so the Commission is not in a position to give an authoritative overview of what currently applies where. The key point is that there is now a single legal framework applicable across the EU.

An efficient intellectual property framework constitutes a precondition for the confidence and willingness of foreign investors to enter into economic commitments in any country. The legal and organizational infrastructure for the protection of intellectual property has the same importance for the technological, economic and cultural development of a country as roads and bridges do for the transport of goods and services.

The accelerating trend towards global patterns of economic and commercial activity, fueled by rapid developments in technology in worldwide communication systems, has brought intellectual property into the mainstream of economic, social, cultural and technological policy in most of the countries. As a result, intellectual property has been transformed from a sleepy area of law and business to one of the driving engines of a high technology economy.

The starting point is the market economy approach, the structure of market product: how to upgrade the functional, formal and marketing quality of manufactured products in the market place by using the resource of creations of the mind and other intellectual values protected by 


\section{Technologies, innovation management and technology transfer}

intellectual property as a set of practical legal tools, as a legal "keyboard" by which the protection system is operated.

This piece of writing is designed to give a pragmatic orientation providing checklists of options for market decisions, for the protection of intellectual property, in order to facilitate the understanding of the fundamentals of the system. It reduces to the essential the intellectual property categories, based on their most general, simplified, internationally and regionally accepted features in the European (continental) type of laws with reference to certain specific features of the intellectual property laws of the United States of America.

Author would like to provide help and referring for details and updates mainly to the relevant websites of the network of national laws, international treaties and various organizations that are active in the field of intellectual property protection. This is a consequence of the fact that the specific information varies from country to country and from region to region, and is rapidly changing in time both at the regional and global levels. Therefore, in concrete cases, the information has to be checked and studied in detail from the respective Internet resources.

\section{Biotechnological inventions}

"Biotechnological inventions" are inventions which concern a product consisting of or containing biological material or a process by means of which biological material is produced, processed or used. "Biological material" is defined as any material consisting of or containing genetic information and capable of reproducing itself or being reproduced in a biological system. The biological material may be of microbiological, plant, animal or human origin, subcellular, unicellular or multicellular organisms and biologically active material.
Biotechnological inventions may have very significant effect in the fields of medicine, food, energy and the protection of environment.

Biotechnological inventions belong to the broad and open concept of invention which is accepted worldwide in accordance with the TRIPS norms. Therefore, the legal protection of biotechnological inventions does not require the creation of a separate body of law and the national patent laws are the essential basis for their legal protection.

Nevertheless, the application of patentability standards demonstrates certain special features regarding:

- the technical character of biotechnological inventions and their demarcation from discoveries and the public domain;

- their industrial applicability, their novelty and their non-obviousness;

- their conformity to the ordre public, morality; and

- their disclosure to the public.

Regarding the patentability of biotechnological inventions, the relevant distinction is not between living and inanimate things, but between products of nature, whether living or not and human-made inventions, between nature and technology. On the other hand there is no possibility for "patenting the life" in general but patenting inventions regarding specific living things which are usually commodities on the market (yeast, flowers, pets etc.) and are object of tangible property. The main issue is the following: whether the biotechnological invention represents such type, degree and level of human intervention into the natural things and processes which reaches the threshold line of the standards of patentability.

As to the technical character of human intervention, generally speaking it has to produce an artificially created state of affairs in natural things and processes. This requirement aims at checking that no mere discoveries or 


\section{Special Issue}

natural things may be patented. The European Biotechnology Directive eliminates any doubts about the technical, man-made or artificial character of biological material where, though naturally occurring, the material has been isolated or produced by a human intervention, by an intellectual input into the natural process. This means that patents are not obtainable for the discovery of biological material in its natural state or for essentially biological processes, but isolated biological materials or materials that are the product or processes of human ingenuity are patentable. This particularly applies to genes which are isolated from their natural environment by means of technical processes and made available for industrial production.

As to the novelty of the said human intervention the general rules apply: it shall not belong to the existing prior art, including the public domain and the inventions under patent protection. The application of the requirement of inventive step/non-obviousness has its specificity because the techniques of isolation are usually standard routine. According to the examination practice, a process of making or using a novel and non-obvious biotechnological product is treated as being itself non-obvious.

One of the key issues of patentability is the industrial application (or in the US patent law: utility). An invention shall be considered as susceptible of industrial application if it can be made or used in any kind of industry, including agriculture.

Biological inventions are patentable if the biological material used by the invention indicates a function or specific, substantial and credible utility. For the evaluation of the patentability it is required for example that the industrial application of a sequence or a partial sequence of a gene must be disclosed in the patent application. A mere DNA sequence per se without indication of a function does not contain any technical information and is therefore not a patentable invention. Inventions are protected in relation to the disclosed industrial application (utility, function) and the breadth of claim shall be commensurate with the contribution to the art shown by disclosure.

Accordingly, the industrial application of a sequence or a partial sequence of a gene must be disclosed in the patent application.

There are some optional exceptions to the general rule of patentability which also apply to biotechnological inventions and counter-exceptions to the optional exceptions. Members of WTO may exclude from patentability:

- inventions, the prevention within their territory of the commercial exploitation of which is necessary to protect ordre public or morality, including to protect human, animal or plant life or health or to avoid serious prejudice to the environment, provided that such exclusion is not made merely because the exploitation is prohibited by their law;

- diagnostic, therapeutic and surgical methods for the treatment of humans or animals; - plants and animals and essentially biological processes for their production; counterexception in this respect: the exclusion cannot relate to microorganisms, non-biological and microbiological processes which are patentable under the general rule. Regarding the protection of plant varieties, there is a special rule: members must provide for the protection of plant varieties either by patents or by an effective sui generis system (UPOV) or by any combination thereof.

As to the possibility of exclusion from the general patent protection of plants and animals, the industrialized countries usually do not provide for such exclusion. This means that a higher grouping of transgenic plants or animals defined by a shared characteristic ("common transgene") is patentable even if it comprises new varieties of plants or animals.

SCIENCE AND INNOVATION. N 4, 2005 


\section{Technologies, innovation management and technology transfer}

Patents are broad and strong forms of biotechnological invention protection, while the plant breeders' right is focusing mainly on the propagating material of the specific embodiment of a variety.

Animal varieties or breeds produced by traditional biological methods have no sui generis legal system for their protection comparable to plant breeders' rights.

However, genetically modified animals and the application of animal organs or parts (like genes, cell lines, egg cells, embryos, organs for xeno?transplantation, etc.) can be patentable since this is not confined to a particular animal species, through the genetic engineering treatment a massive?human intervention, a technical breeding process is present for useful purposes.

As to the requirement of conformity of biotechnological inventions with the ordre public, it expresses the precautionary public policy against possible unforeseeable dangers, risks, and hazards to the life, health and environment. "Morality" relates to the totality of conventionally accepted ethical norms according to which certain acts are right, others are wrong (e.g., using animals for clinical tests is right, but cruelty to them, causing them unnecessary suffering is wrong). It is the general opinion in patent practice that the mere fact that genetic manipulation is used does not render an invention immoral.

The patent laws provide that exploitation shall not be deemed to be contrary to the ordre public or morality merely because is prohibited by law or regulation. It means that there is a difference between patenting and exploitation. Morality issues arise regarding animals and humans.

The animal biotechnology is dominated by ethical questions concerning the allowable limits of human interference into the nature by the genetic recombination of animals which may lead to the loss of genetic diversity, loss of integrity of certain species by the chimerical animals, with no direct benefit, with unforeseeable consequences and suffering for the animals.

The European Biotechnology Directive tried to strike a balance and maintain proportionality between the medical benefits and the sufferings providing that shall be considered unpatentable the processes for modifying the genetic identity of animals which are likely to cause them suffering without any substantial medical benefit in terms of research, prevention, diagnosis or therapy to man or animal and also animals resulting from such processes.

It is a widely accepted axiom of the patent law that the human body per se and its organs are not patentable. According to the Directives, the human body, at the various stages of its formation and development, and the simple discovery of one of its elements, including the sequence or partial sequence of a gene, cannot constitute patentable inventions.

But this is not true to the application of certain parts of the human body which are separated, e.g. certain tissues, DNA sequences that are taken out of the body and used for the production of human-derived medicines (insulin, interferon, etc.) i.e. when a human part is used as a constituent of an invention. It is expected that this activity will be even more intensive due to the publication of Human Genome Map.

According to the Directives, an element isolated from the human body or otherwise produced by means of a technical process, including the sequence or partial sequence of a gene, may constitute a patentable invention, even if the structure of that element is identical to that of a natural element.

If an invention is based on biological material of human origin or if it uses such material, where a patent application is filed, the person from whose body the material is taken must have had an opportunity of expressing free and informed consent thereto, in accordance with national law. 


\section{Special Issue}

On the basis of violation of ordre public or morality, the following in particular shall be considered unpatentable in this respect:

- processes for cloning human beings, including techniques of embryo splitting, designed to create a human being with the same genetic information as another living or deceased human being;

- processes for modifying the germ line genetic identity which influences the following generations of human beings; but this does not exclude somatic gene therapy of a certain person without influencing the following generations;

- use of human embryos for industrial or commercial purposes; in any case such exclusion does not affect inventions for therapeutic or diagnostic purposes which are applied to human embryos and are useful to it.

The patentability of genetic engineering relating to human stem cells is under discussion. This list is non-exhaustive and is to be seen as giving concrete form to the concepts of ordre public and morality.

According to the TRIPS Agreement, members may also exclude from patentability: diagnostic, therapeutic and surgical methods for the treatment of humans or animals.

According to the EPC, methods for treatment of the human or animal body by surgery or therapy and diagnostic methods practiced on the human or animal body shall not be regarded as inventions which are susceptible of industrial application. This provision shall not apply to products, in particular substances or compositions for use in any of these methods.

The methods of diagnosis practiced on humans or animals and of treatment of humans or animals by surgery or therapy, including gene-therapy are eligible to be patented in some countries (Australia, Japan and Korea for animals only, New Zealand, surgery with respect of cosmetic surgery, therapy for animals only, United States of America). On the other hand, several countries are excluding such processes from patentability.

Biopharmaceutical products produced by gene therapy techniques are eligible to be patented everywhere except products used in germ line gene therapy.

The second medical use claims of genederived products in the form "Use of substance $\mathrm{X}$ to treat illness $\mathrm{Y} "$ are also eligible to be patented if the use of the substance is taught for a new therapeutic purpose susceptible of industrial application (so-called "Swiss-style claims").

Besides the patentability of biotechnological inventions another issue is the scope of protection (extension and limitation) regarding the biological material and the process that enables a biological material to be produced.

The Biotechnology Directive provides for an important extension of the scope of patent protection for biological material and processes. Protection for genetic material possessing specific characteristics as a result of the invention extends to all biological material obtained from propagation or multiplication of the protected material. For example, a patent extends not only to the microorganisms in which a foreign DNA sequence has been inserted but also to the proteins, hormones, enzymes produced by it. Similarly a patent for a process will cover all products directly obtained from that process and material obtained through propagation or multiplication of products directly obtained from the process ("product by process protection").

On the other hand, the Biotechnology Directive provides for an important limitation of the scope of patents for plants and animals in favor of farmers. The sale or other form of commercialization of plant propagation material to a farmer by the holder of the patent or with his consent for agricultural use implies authoriza- 
tion for the farmer to use the product of his harvest for propagation or multiplication by him on his own farm. This means that he is not obliged to buy new genetically modified seed each year.

The sale or any other form of commercialization of breeding stock or other animal reproductive material to a farmer by the holder of the patent or with his consent implies authorization for the farmer to use the protected livestock for an agriculture purpose. This includes making the animal or other animal reproductive material available for the purposes of pursuing his agricultural activity but not sale within the framework or for the purpose of a commercial reproduction activity.

In order to avoid conflicts between the complementary legal forms of gene patents and genetically engineered varieties, the Biotechnology Directive provides for compulsory crosslicensing between patentees and holders of earlier plant variety rights, and vice versa.

Where a breeder is unable to acquire or exploit a plant variety right without infringing a prior patent, he may seek a compulsory license on "reasonable terms" from the patentee for non-exclusive use of the patent. He must demonstrate that he has applied unsuccessfully to the holder of the prior patent for a contractual license and that the plant variety constitutes significant progress. The same applies reciprocally to a patentee who finds himself unable to exploit his patent without infringing a prior plant variety right.

Another alternative and complementary possibility of protection of biotechnological inventions is offered by trade secret law (undisclosed information protection).

The use of trade secret protection is limited regarding the biotechnological inventions due to the self-replicating character of biological material by which it can be reproduced without disclosing the secret. From the point of view of public interest, the patenting is preferable because the full disclosure of the invention gives an inspirational information for further research and the invention does not die together with the inventor.

\section{Conclusion}

It is widely recognized that over the last decade, economic, technological and political factors have influenced the increasing importance of intellectual property protection.

Globalization and the liberalization of world markets have intensified competition among companies. Increasingly, constantly renewing resources of an intellectual nature, as opposed to physical assets, are of crucial importance to businesses.

At a corporate level, it is widely realized that intellectual property protection, particularly of inventions, designs and trademarks, represents intangible assets which provide an important competitive edge in technological innovation and marketing. Creating and developing such assets involves substantial investment and risk-taking by venture capital. Their use introduces sophisticated and distinctive products in the market and is therefore linked as a powerful tool to economic growth and cultural development. This often generates employment, considerable income, promotes technological and cultural advances and enriches the pool of public knowledge and culture.

On the other hand, the intellectual property system has been challenged by revolutionary technological advances that had been made in the fields of information technology and biotechnology over the last decade. Such technologies are difficult and expensive to develop, but easy and cheap to imitate, therefore requiring more protection than traditional technologies.

As a consequence of economic and technological advances, the need for appropriate intellectual property protection has been recognized and politicized at national, regional and global 


\section{Special Issue}

levels of trade policy. The Agreement on TradeRelated Aspects of Intellectual Property Rights (TRIPS Agreement) is the result of this global recognition.

Disclaimer: this material does not give legal advice. The information contained in it is not meant to replace proper legal advice. The views and opinions expressed in it do not necessarily state or reflect those of the World Intellectual Property Organization (WIPO). WIPO does not assume any legal liability or responsibility for the accuracy, completeness or usefulness of any information contained in it.

Acknowledgment: the information selected and arranged in this work is believed to be "common knowledge" and its public domain sources are many and varied, mainly those of WIPO, WTO and EU public, legal and information materials. Whilst there has been no verbatim copying, if some has been gleaned from copyrightable publications, this is gratefully acknowledged at the request of authors.

\section{SELECTED INTELLECTUAL PROPERTY WEBSITES}

\section{Intellectual Property links in general}

- IP Menu - The Home of Intellectual Property on the Internet: http://www.ipmenu.com ;

- Munich Intellectual Property Law Center - Links: http://www.miplc.de/links.htm ;

- $\quad$ EPO - Patent information on the Internet (link collection): http://www.european-patent-office.org/ online/index.htm ;

- $\quad$ ELDIS Intellectual Property Rights Resource Guide: http://www.eldis.org/ipr ;

- QuickLinks: Daily Update on IP \& Internet Law: http://www.qlinks.net/quicklinks/index.shtml ;

- Intellectual Property News Matrix: http://intelproplaw.com/NewsSrch.shtml ;

- The Patent Blog: http://www.patentblog.com ;

- The Copyright Blog: http://www.copyrightblog.com
- $\quad$ The Trademark Blog: http://trademarkblog.us/blog Franklin Pierce IP Mail Web Resources: http://www.ipmall.piercelaw.edu ;

- Mayall's IP Links (John Mayall, U.K.): http://www.mayallj.freeserve.co.uk ;

- $\quad$ European \& International IP Links (Ralph Beier, von Bezo): http://www.ip-firm.de/links.htm ;

- European Union Internal Market Industrial Property Page: http://europa.eu.int/comm/internal market/en/indprop/i ;

- European Union IPR Helpdesk: http://www.iprhelpdesk.org ;

- EurActiv.com Portal - Links Dossier.

\section{Global international organizations}

- World Intellectual Property Organization (WIPO): http://www.wipo.int ;

- International Union for the Protection of New Varieties (UPOV): http://www.upov.int;

- World Trade Organization (WTO) Intellectual Property: http://www.wto.org ;

- UNESCO Copyright Page: http://www.unesco.org/culture/copyright ;

- Organization for Economic Cooperation and Development (OECD): http://www.oecd.orgopic/ 0,2681,en $264934797 \quad 1 \quad 1 \quad 1$;

- International Chamber of Commerce Intellectual Property: http://www.iccwbo.org/home/ menu_intellectual_property ;

- Intellectual Property Constituency of ICANN: http://www.ipc.dnso.icann.org ;

\section{Regional Intellectual Property Offices}

- European Patent Office (EPO): http://www.european-patent-office.org/index.htm ;

- Eurasian Patent Organization (EAPO):

http://www.eapo.org;

- European Union Trade marks \& Designs, Office of the Internal Market (OHIM):

http://www.oami.eu.int/en/default.htm ;

- Community Plant Variety Office (CPVO): http://www.cpvo.fr ;

- Benelux Trademarks Office: http://www.bmbbbm.org ;

- Benelux Designs Office: http://bbtm-bbdm.org ;

- African Intellectual Property Organization (AIPO/OAPI): http://www.oapi.wipo.net/en/index.html ; African Regional Industrial Organization (ARIPO):

SCIENCE AND INNOVATION. N 4, 2005 


\section{Technologies, innovation management and technology transfer}

\footnotetext{
http://www.aripo.org ;

- Asia-Pacific Economic Cooperation (APEC) Intellectual Property Experts Group: http://www.apecipeg.org ;

- Patent Office of the Cooperation Council For the Arab States of the Gulf: http://gulf-patent-office.org ;

- Trilateral website (EPO-JPO-USPTO):

http://www.european-patent-office.org/tws/twsindex.htm .
}

\section{National Intellectual Property Offices}

- WIPO Directory of National and Regional Industrial Property: http://www.wipo.int ;

- Web Sites of Industrial Property Authorities Worldwide:

http://www.wipo.orgews/en/links/ipo_web.htm ;

- Patent Offices on the WWW: http://www.piperpat.co.nz/resource/patoff.html .

\section{Intellectual Property Laws}

- Collection of Laws for Electronic Access (WIPO): http://clea.wipo.int;

- European Community IP Regulations \& Directives: http://europa.eu.int/eur-lex/en/lif/reg/en_register

- Europa-Gateway to EU: http://europa.eu.int/scadplus/leg/en/s06020.htm .

\section{Representatives}

- European Patent Office Database of Professional Representatives: http://www.european-patentoffice.org/reps/search.html ;

- PIPERS worldwide directory of intellectual property attorneys:

http://www.piperpat.co.nz/resource/world.html ;

- International Federation of Intellectual Property Attorney: http://www.ficpi.org ;

- Association of Patent Law Firms:

http://www.aplf.org ;

- $\quad$ European Patent Institute (EPI): http://www.patentepi.com/nix.html .

\section{Databases}

- WIPO Intellectual Property Digital Library: http://www.wipo.int/ipdl/en/index.jsp ;

- $\quad$ European Patent Office (EPO): http://www.espacenet.com ;

- Community Trade Mark (EU) Database: http://oami.eu.int/searchtrademark/la/en_tm_sear ch ;

- USPTO Web Patent Database: http://www.uspto.gov/patft/index.html .

\section{Enforcement of IP rights}

- WIPO Arbitration and Mediation Center: http://arbiter.wipo.int ;

- World Trade Organization TRIPS Dispute Settlement:

http://www.wto.org/englishratop_erips_e/intel5_e ;

- WIPO Internet Domain Name Arbitration Decisions: http://arbiter.wipo.int/domains/decisions/index.htm ;

- World Customs Organization (WCO): http://www.wcoomd.org/ie/index.html ;

- The Coalition for Intellectual Property Rights: http://www.cipr.org ;

- International Anti-Counterfeiting Coalition: http://www.iacc.org/teampublish/109_467_1832.C $\mathrm{MF}$ ?CFID $=1104 \ldots$;

- REACT European Anti-Counterfeiting Network: http://demo.snbreact.nl/snbdemo/topinactive.htm .

\section{Intellectual Property Associations}

- International Association for the Protection of Intellectual Property: http://www.aippi.org ;

- American Intellectual Property Law Association (AIPLA): http://www.aipla.org ;

- International Trademark Association (INTA): http://www.inta.org ;

- Intellectual Property Owners Association (IPO): http://www.ipo.org ;

- International Federation of Inventors' Associations: http://www.invention-ifia.ch ;

- Association of European Trade Mark Owners (MARQUES): http://www.marques.org ;

- Licensing Executive Society International (LEI): http://www.les.org ;

- Business Software Alliance (BSA): http://www.bsa.org/usa ;

- International Intellectual Property Alliance (IIPA): http://www.iipa.com ;

- International Intellectual Property Institute (IIPI): http://www.iipi.org ;

- Broadcast Music International (BMI): http://www.bmi.com/home.asp ; 


\section{Special Issue}

- International Confederation of Societies of Authors: http://www.cisac.org/web/content.nsf/Builder?Rea dForm ;

- European Communities Trade Mark Association (ECTA): http://www.ecta.org

- Entertainment Software Association (ESA): http://www.theesa.com;

- International Federation of the Phonographic Industry (IFPI): http://www.ifpi.org;

\section{Research and Teaching of Intellectual}

\section{Property}

- International Association for the Advancement of Teaching and Research in Intellectual Property: http://www.atrip.org ;
- $\quad$ "Centre d'etudes internationales de la propriete intellectuelle" (CEIPI): http://www.ceipi.edu/gb/sectioninternationale/formation.html ;

- Munich Intellectual Property Law Center: http://www.miplc.de ;

- Max Planck Institute for Intellectual Property: http://www.intellecprop.mpg.de/enhanced/english/home ;

- Center for Intellectual Property Law - John Marshall:

http://www.jmls.edu/catalog.cfm?dest=dir\&linkon= ;

- Intellectual Property Program - Franklin Pierce Law: http://www.piercelaw.edu/academics ip.htm ;

- WIPO Worldwide Academy (Switzerland): http://www.wipo.int/academy . 